\begin{tabular}{c}
\hline \hline OPEN \\
JOURNAL \\
SYSTEMS \\
\hline \hline ISSN:2237-2202
\end{tabular}

Available on line at Directory of Open Access Journals

Journal of Hyperspectral Remote Sensing v.9, n.6 (2019) 343-352

www.periodicos.ufpe.br/revistas/jhrs

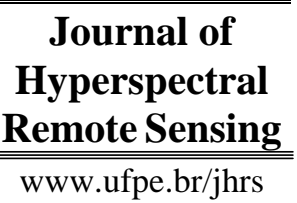

\title{
Use of Vegetation Cover Index (ICV) to identify susceptible areas to desertification process in the municipalities of Betânia, Floresta and Itacuruba, Pernambuco, Brazil
}

\author{
Rayanna B. de O. Alves ${ }^{*}$, Hernande P. da Silva ${ }^{* *}$, José C. de Araújo Filho ${ }^{* * *}$, Marco A. de O. Domingues ${ }^{* * * *}$, \\ Jones O. de Albuquerque
}
*Institute for Risk and Desaster Reduction of Pernambuco-IRRD-PE/UFRPE, Geoprocessing and Remote Sensing Laboratory/Federal Rural University of Pernambuco GEOSERE/UFRPE, Recife-PE, Brazil. E-mail: rayannabarroso@hotmail.com (Corresponding author)
** IRRD-PE/UFRPE, GEOSERE, UFRPE, Recife-PE, Brazil. E-mail: hernandepereira@ yahoo.com.br
**** Brazilian Agricultural Research Corporation-EMBRAPA, National Soil Research Center, UEP Recife, Recife-PE, Brazil. E-mail: coelhoembrapa@gmail.com
**** Federal Institue of Pernambuco, Recife-PE, Brazil. E-mail: coelhoembrapa@gmail.com
IRRD-PE/UFRPE, Keiso Azami Laboratory-LIKA/UFPE, UFRPE, Recife-PE, Brazil. E-mail:
hernandepereira@yahoo.com.br

Received 10 November 2019; accepted 20 December 2019

\begin{abstract}
Climate change in Brazil has led to an increase in temperature and changes in the distribution of climatic extremes, such as droughts, droughts, floods and floods. This is potentialized when it comes to the semi-arid Northeast. Environmental studies related to this theme are in constant development. For this, the geotechnologies are of great importance for the environmental studies, since they allow the acquisition and analysis of information of use of the ground, vegetal cover and phenomena of the nature. In the present work, the Vegetation Cover Index was studied using remote sensing and geoprocessing techniques through the digital processing of images acquired in the years 2000 to 2015 of the LANDSAT satellites of three municipalities of Pernambuco to observe the vegetation cover in the said temporal space with the degraded areas possibly resulting from the desertification process in the region. Thus, it was found that the municipalities of Betânia and Itacuruba have very high vulnerability $(0.75$ and 1 , respectively). On the other hand, the municipality of Floresta presented a high vulnerability of ICV $(0.5)$, as the vegetation deficit influences hydrological dynamics, soil protection, climatic stability and thermal influence, corroborating the desertification process.

Keywords: climate change, desertification, environmental vulnerability.
\end{abstract}

\section{Introduction}

In Brazil, the municipalities influenced by extreme events (drought and drought) are increasing and the drought stage is getting worse. The northeast region is vulnerable to the risks of climate variability which can cause aridization and consequent desertification due to climate change.

Natural systems are vulnerable to climate change and suffer from loss of biodiversity significant and irreversible impact. As a result, the geographic extent of damage or loss to the affected systems greatly increases the rate of climate change.

Available evidence indicates that changes in climate, particularly rising temperatures, have already affected diverse sets of physical and biological systems. Anthropic activities such as pollution and factors in land use change have also been acting on these systems, affecting the population of various localities and / or regions. The vulnerability of human populations and natural systems to climate change differs substantially from region to region (Mccarthy et al., 2001).

Some are particularly vulnerable due to their physical exposure to climate change risks and / or their limited adaptability. Least-developed regions are especially vulnerable, as most of their economy comes from climate-sensitive sectors and their human, financial and natural resources capacity is low, as well as they have limited institutional and technological resources.

In Brazil, the existence of desertification processes was initiated by Vasconcelos Sobrinho, and began to be strongly addressed in the 1970s (Sales, 2002).

According to Vasconcelos Sobrinho (1978), desertification can be defined as "the process of progressive and vegetal degradation of soil and water resources, resulting from climatic conditions and soil conditions or human actions, or both, leading to the 
destruction of the primary ecosystem, reduced productivity and loss of soil self-healing capacity".

Vegetation cover has the purpose of regulating soil stability without leading to erosion; regulates hydrological cycles, water supply, maintains soil fertility, and as a consequence, food generation (Souza et al., 2009), thus conserving areas that may have influences to develop the desertification process.

Vegetation cover is perhaps the most important factor controlling the phenomenon of desertification in semi-arid space. Even deciduous, the caatinga still plays the role of protecting the soil against the weather, reducing its degradation. This finding categorically states that the main cause of erosion in this region is undoubtedly the unbridled devastation of vegetation with the aim of meeting the need for more agricultural areas and the supply of wood for fences and other purposes (Sá et al., 2015).

In areas affected by desertification in the semi-arid regions of northeastern Brazil, the vegetation is small and larger and spaced between its components than in other areas, generally coinciding with the presence of open hyperxerophilous caatinga. The fundamental characteristic of the desertification phenomenon in the northeastern semi-arid region is the presence of exposed soil patches (Galindo et al., 2008).

According to Field (2014), significant vulnerability and exposure of some ecosystems and many human systems to climate variability generate impacts that are caused by recent extreme weatherrelated events such as heat waves, droughts, floods, cyclones, and fires. In many regions, changes in rainfall are affecting quality and quantity water reserves and altering hydrological systems.

Exposure variables are used to study environmental and human vulnerability to desertification processes, and one of them is the Vegetation Coverage Index (ICV).

Vegetation cover has the purpose of regulating soil stability without leading to erosion; regulates hydrological cycles, water supply, maintains soil fertility, and as a consequence, food generation (Souza et al., 2009), thus conserving areas that may have influences to develop the desertification process.

Biodiversity protection can also have a mitigating effect on infectious diseases. In addition, the choice of this component is due to the fact that the larger the native vegetation cover area of a locality, the greater the health and welfare benefits of the communities living in its vicinity (Civitello, 2015).

According to Silva (2009), desertification is a spatial phenomenon and as such can be treated within a Geographic Information System (GIS). The analysis tools of a GIS allow to establish spatial correlations and diverse modeling for the most varied data such as those derived from desertification process indicators.

Remote sensing has been used to monitor droughts (Rodrigues, 1997) and to delimit degraded areas susceptible to desertification processes in the state of Ceará (Soares et al., 2010).

Like this, geoprocessing and remote sensing techniques have been used to monitor droughts and delimit degraded areas that are susceptible to desertification processes, contributing to analyzes in order to continuously monitor the affected areas and develop preventive environmental actions.

As soon, this article is part of the work developed by the author in her master's dissertation and calculates the ICV, which allows the assessment of environmental vulnerability related to vegetation, where damage can be indicated and estimated. in vegetation cover and presence of exposed soil related to desertification municipalities of Betânia, Floresta and Itacuruba in Pernambuco State, Brazil.

\section{Material and methods}

\section{Study area characterization}

The studied area is located in Pernambuco semi-arid, in the Sertão Pernambucano and São Francisco Pernambucano mesoregions, and Pajeú Sertão and Itaparica microregions respectively (Figure 1).

\section{Betânia County}

Betânia county is inserted in the caatinga biome, has a total area of $1.244,074 \mathrm{~km}^{2}$ with population of 12.003 (IBGE, 2010a) and it is located in the northern part of the Pajeú microregion, northern portion of the state of Pernambuco, and is geographically limited to the north with the municipalities of Flores and Calumbi, to the south with Floresta, to the east with Custódia and to the west with Serra Talhada and forest (CPRM, 2005).

The vegetation cover is mainly composed of Hyperxerophilous Caatinga with sections of deciduous forest. The climate is Tropical Semi-Arid, with summer rainfall. The rainy season begins in November and ends in April. The average annual rainfall is 431,8 $\mathrm{mm}$ (CPRM, 2005).

\section{Floresta County}

According to Silva, 2009, "The municipality of Floresta is located in the mesoregion of São Francisco Pernambucano and microregion of Sertão de Itaparica. It is limited to the north with the municipality of Serra Talhada, Betânia and Custódia, to the west with Carnaubeira da Penha and Itacuruba, to the south with Tacaratu, Petrolândia and Bahia 
State, to the east with Inajá, Ibimirim".

The predominant vegetation in the municipality of Floresta is the hyperxerophilous caatinga (Araújo Filho, 2001), there are also sections of deciduous forest in mountainous environments (Rodal et al., 2002).

\section{Itacuruba County}

Itacuruba is located in the Sertão do São Francisco mesoregion and Sertão de Itaparica microregion, inserted in the Caatinga biome. It has a population of 4,369 inhabitants and a territorial extension of 430,038 $\mathrm{km}^{2}$ (IBGE, 2010b).

The municipality is located in the São Francisco River macro basin and Pajeú River basin, and belongs to the Borborema Province, which is located south of the Pernambuco lineament. Its relief is characterized as smooth-wavy, and cut by narrow valleys with dissected slopes. The vegetation is xerophilic, alternating in dry months as deciduous with minor intrusions of xerophytism. It is represented by species such as mandacaru, crown of friar, gentian, xique-xiques, catingueira, pereiro and slum (Rocha Filho, 2016).

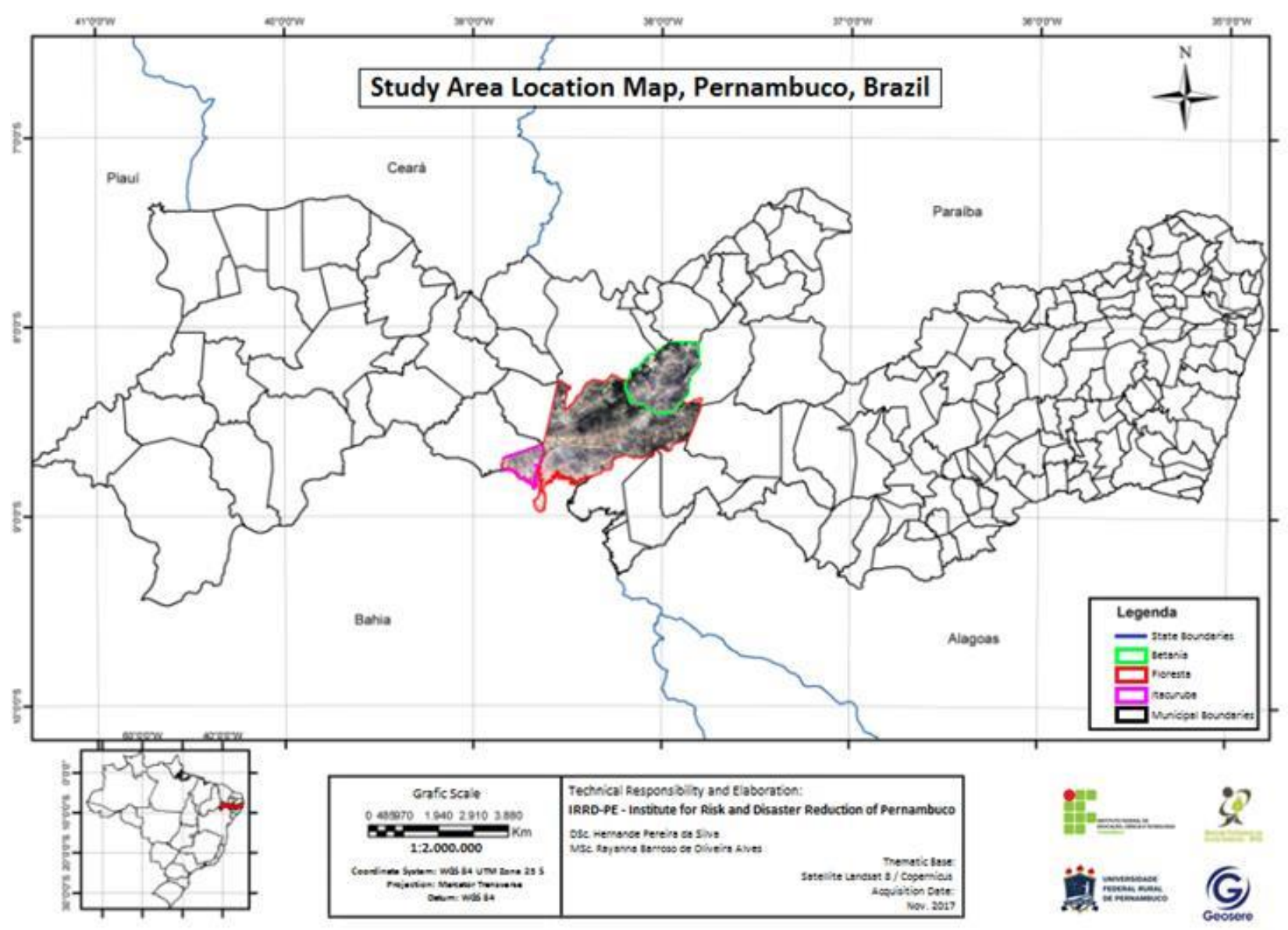

Figure 1 - Geographic localization of the study area.

\section{Landsat Image Selection and Acquisition}

The research and treatment of the images were developed at the Geoprocessing and Remote Sensing Laboratory - GEOSERE, more precisely at the RRS (Recife Receiving Station), located at the Federal Rural University of Pernambuco. A historical series of Landsat 5 and Landsat 8 satellite images from 2000 to 2015 were chosen, excluding 2012, since the Landsat 7 satellite sensor has errors in the images and is impossible to use.

The Landsat 5 scenes were acquired by the database of the National Institute for Space Research - INPE. Landsat 8, in its own spatial database developed by the United States Geological Survey USGS. Thus, the bands 3,4,5 (BGR) and 4,5,6 (BGR), respectively, were used (Table 1). 
Table 1 - Landsat Scenes Features.

\begin{tabular}{cccc}
\hline Satellite & Orbit & $\begin{array}{c}\text { Spectral } \\
\text { Bands }\end{array}$ & $\begin{array}{c}\text { Date of } \\
\text { acquisition }\end{array}$ \\
\hline LANDSAT 5 & 216 & $3,4,5$ & $24 / 09 / 2000$ \\
LANDSAT 5 & 216 & $3,4,5$ & $06 / 05 / 2001$ \\
LANDSAT 5 & 216 & $3,4,5$ & $06 / 03 / 2002$ \\
LANDSAT 5 & 216 & $3,4,5$ & $22 / 12 / 2003$ \\
LANDSAT 5 & 216 & $3,4,5$ & $24 / 12 / 2004$ \\
LANDSAT 5 & 216 & $3,4,5$ & $24 / 10 / 2005$ \\
LANDSAT 5 & 216 & $3,4,5$ & $25 / 09 / 2006$ \\
LANDSAT 5 & 216 & $3,4,5$ & $05 / 04 / 2007$ \\
LANDSAT 5 & 216 & $3,4,5$ & $01 / 11 / 2008$ \\
LANDSAT 5 & 216 & $3,4,5$ & $13 / 06 / 2009$ \\
LANDSAT 5 & 216 & $3,4,5$ & $06 / 10 / 2010$ \\
LANDSAT 5 & 216 & $3,4,5$ & $31 / 10 / 2011$ \\
LANDSAT 8 & 216 & $4,5,6$ & $30 / 03 / 2013$ \\
LANDSAT 8 & 216 & $4,5,6$ & $02 / 10 / 2014$ \\
LANDSAT 8 & 216 & $4,5,6$ & $14 / 03 / 2015$ \\
\hline
\end{tabular}

\section{Image Treatment}

For the treatment of acquired scenes, we used the software SPRING (Georeferenced Information Processing System) developed by INPE, which allows image processing, spatial analysis, numerical terrain modeling and consultation of spatial databases. It was made the clipping, in the cities of Betânia, Floresta and Itacuruba, from the Shape of the municipal limits of the state of Pernambuco and the scenes / images acquired. For better visualization and definition of thematic classes, radiometric correction of the study area was performed.

Thus, radiometric correction was performed from the RGB 3,4,5 color composition for LANDSAT 5 images and 4,5,6 for LANDSAT 8, through contrast equalizing histogram. Based on the methodology used by Alves, 2017, after the previous step, supervised classification began, which is a process of extracting information from images to recognize homogeneous patterns and objects and are used in Remote Sensing to map land surface areas. that correspond to the topics of interest. Thus, it allowed the identification of areas with existing vegetation.

Then the thematic mapping was performed, which allowed the transformation of the classified image (Category Image) to a thematic map.

\section{Calculation of Vegetation Covered Areas}

Completing the previously developed steps, the mapped areas were calculated for each municipality using the Metric Operations tool to identify not only the territorial area unit, but also the relationship between the total area of the municipalities and the vegetation area natural, in percentage.

\section{Vegetation Coverage Index (ICV)}

The ICV was elaborated through the use of geoprocessing and remote sensing techniques - contrast operation, classification and thematic maps elaboration - in order to obtain the total vegetation area of each municipality and the exposed soil areas.

The calculation of the percentage of vegetation cover area in relation to the total area of each municipality was elaborated.

$$
I C V=\text { Weight } \% \text { Vegetation Cover }
$$

The weight values for the ICV were prepared according to the percentage range of vegetation cover, as shown in Table 2, where the value 0 represents lower vulnerability, since a higher percentage of vegetation cover brings environmental, climatic and social benefits; weight 4 corresponds to the minimum vegetative area.

Table 2 - Weights and percentages of vegetation cover.

\begin{tabular}{cc}
\hline Interval $(\%)$ & Weight \\
$>30$ & 0 \\
$20,1-30$ & 1 \\
$10,1-20$ & 2 \\
$5,1-10$ & 3 \\
$0-5$ & 4 \\
\hline
\end{tabular}

The values obtained after performing the previous calculations were interpreted based on the Social Vulnerability Index of IPEA - Institute of Applied Economic Research, in its Social Vulnerability Atlas of Brazilian Municipalities, which ranges from 0 to 1 . The closer to 1 , the greater the social vulnerability of a municipality (Figure 2).

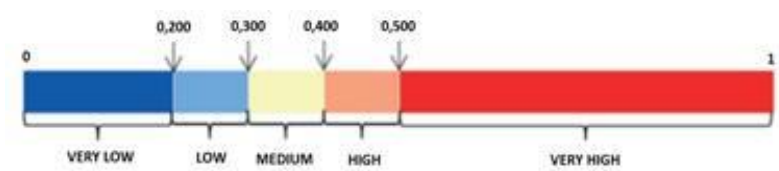

Figure 2 - Social Vulnerability Index Range. Source: IPEA, 2015.

The interval values for the Climate Index were associated with the Social Vulnerability Index developed by IPEA, where it was necessary, for calculations, the intensity weights for each interval (Table 3). 0 to 4 , where 0 is the lowest vulnerability of vegetation cover and 4 the greatest vulnerability of vegetation cover.

Table 3 - Vegetation cover vulnerability index range.

\begin{tabular}{ccc}
\hline ICV & Intensity & Weight \\
$0-0,201$ & Low & 0 \\
$0,201-0,300$ & Very Low & 1 \\
$0,301-0,400$ & Medium & 2 \\
$0,401-0,500$ & High & 3 \\
$0,501-1$ & Very High & 4 \\
\hline
\end{tabular}




\section{Results and discussion}

\section{Vegetation Coverage and Thematic Map Generation}

From the supervised classification of images from 2000 to 2015, in different seasons of the year, it was possible to obtain the result of vegetation cover. The different dates used mainly with regard to the months, was of paramount importance, as they are associated with all seasons of the year, which can be evaluated the outcrop of vegetation in the most diverse climatic conditions.

Therefore, it was possible to identify areas with vegetation cover and areas with exposed soil of the municipalities studied. The colors used to identify the vegetation are related to the year studied and are the same for the three municipalities.

The Figure 3 presents Betânia county egetation cover in the period of 2000 to 2015 .

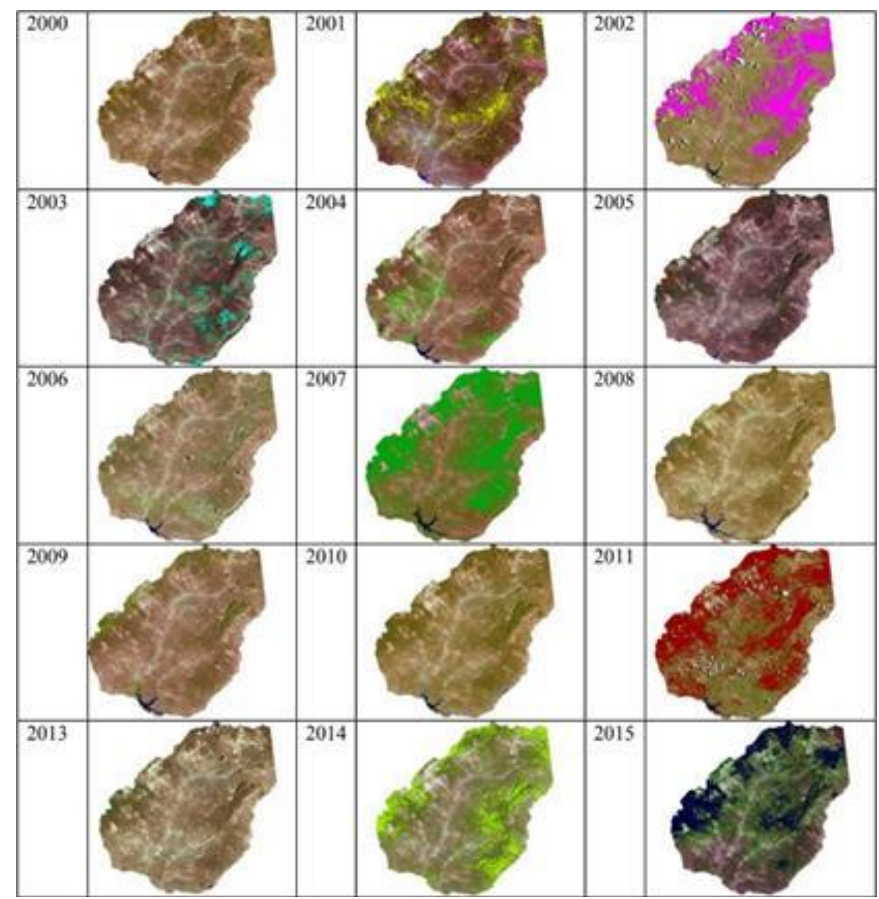

Figure 3 - Betânia county vegetation cover.

Figure 4 shows the municipality of Floresta with vegetation cover from 2000 to 2015 , where it was possible to identify as areas with vegetation cover and as areas with exposed soil.

Figure 5 presents the vegetation cover of the municipality of Itacuruba from 2000 to 2015, where it was possible to identify areas with vegetation cover and areas with exposed soil.

From the classification of the vegetation cover, it was possible to cross each year for all municipalities.

In the Figure 6, we can see in the municipality of Betânia the areas with vegetation cover from 2000 to 2015.

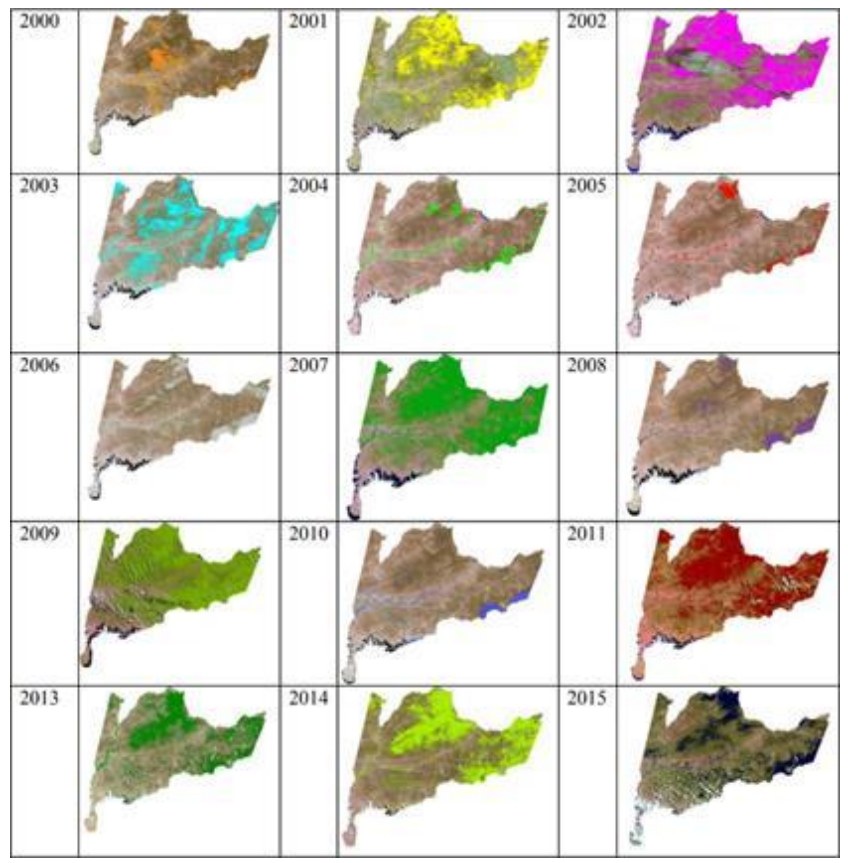

Figure 4 - Floresta county vegetation cover.

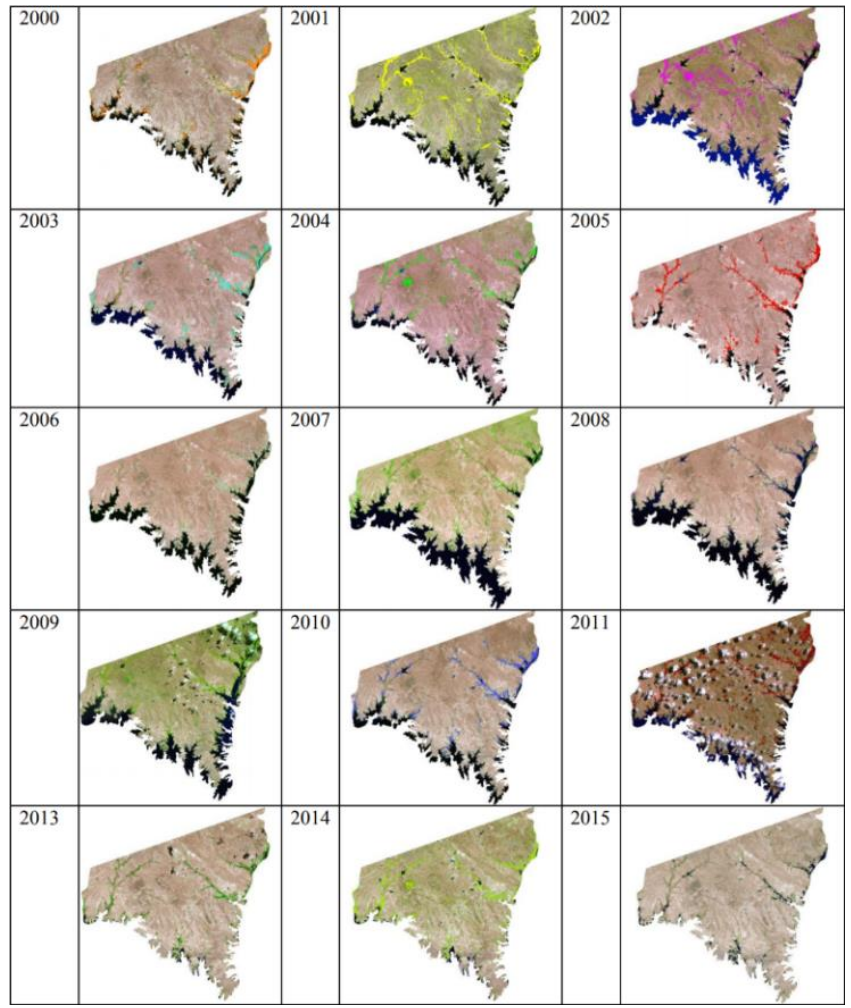

Figure 5 - Itacuruba county vegetation cover. 


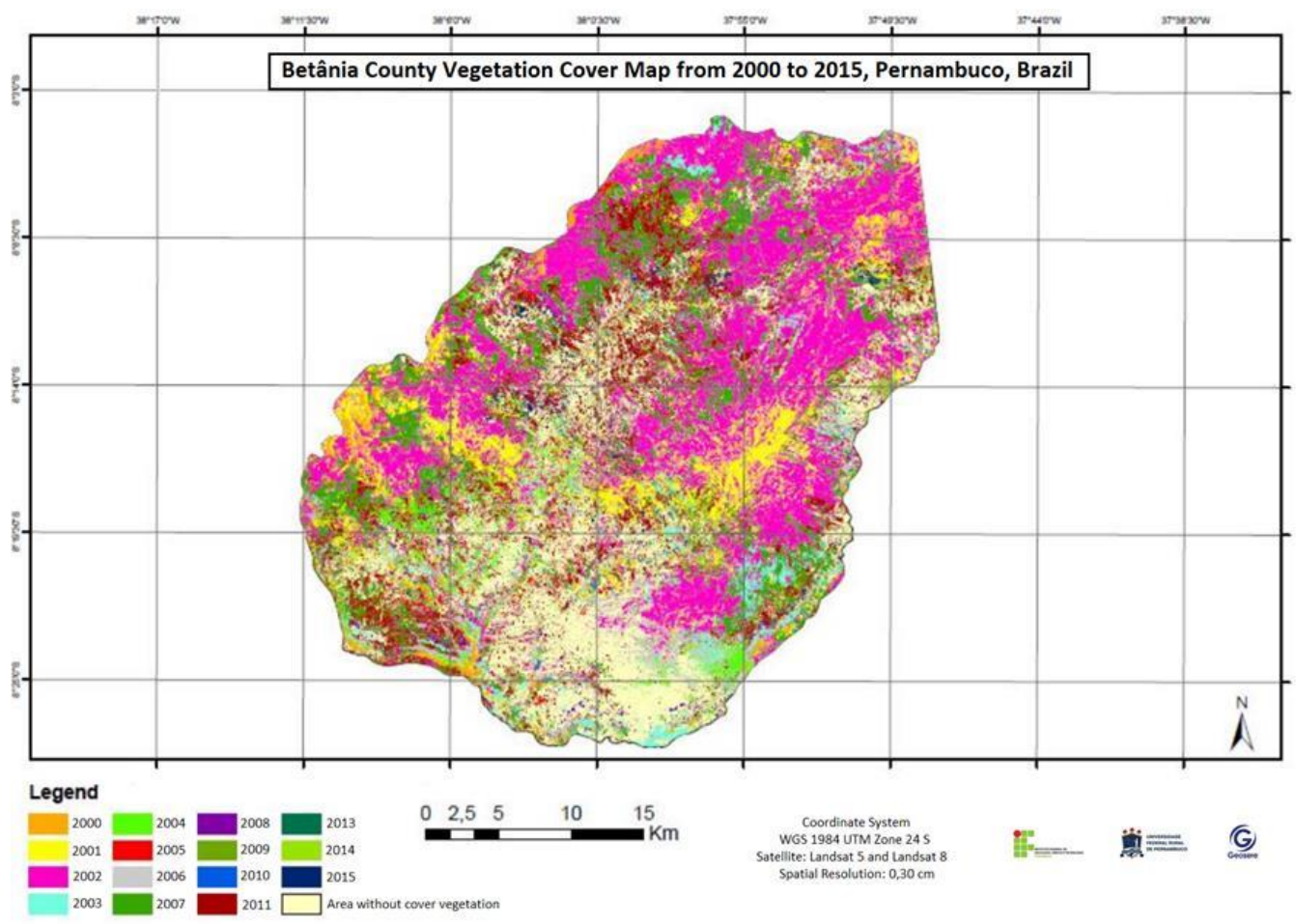

Figure 6 - Betânia county vegetation coverage map.

It was observed that the areas without vegetation cover, over the period studied, have soil classes Luvissolo, Planosolo and Litolic Soil, where the first two have high vulnerability and the third very high vulnerability to desertification processes.

Similarly, the vegetation cover was crossed from 2000 to 2015 to the municipality of Floresta (Figure 7).
It was observed that in the municipality of Floresta, the areas of soil without vegetation cover over the studied period are formed by the soil types Areia Quartzosa, Luvissolo and Litolica Soil, which have very low, high and very high vulnerability, respectively.

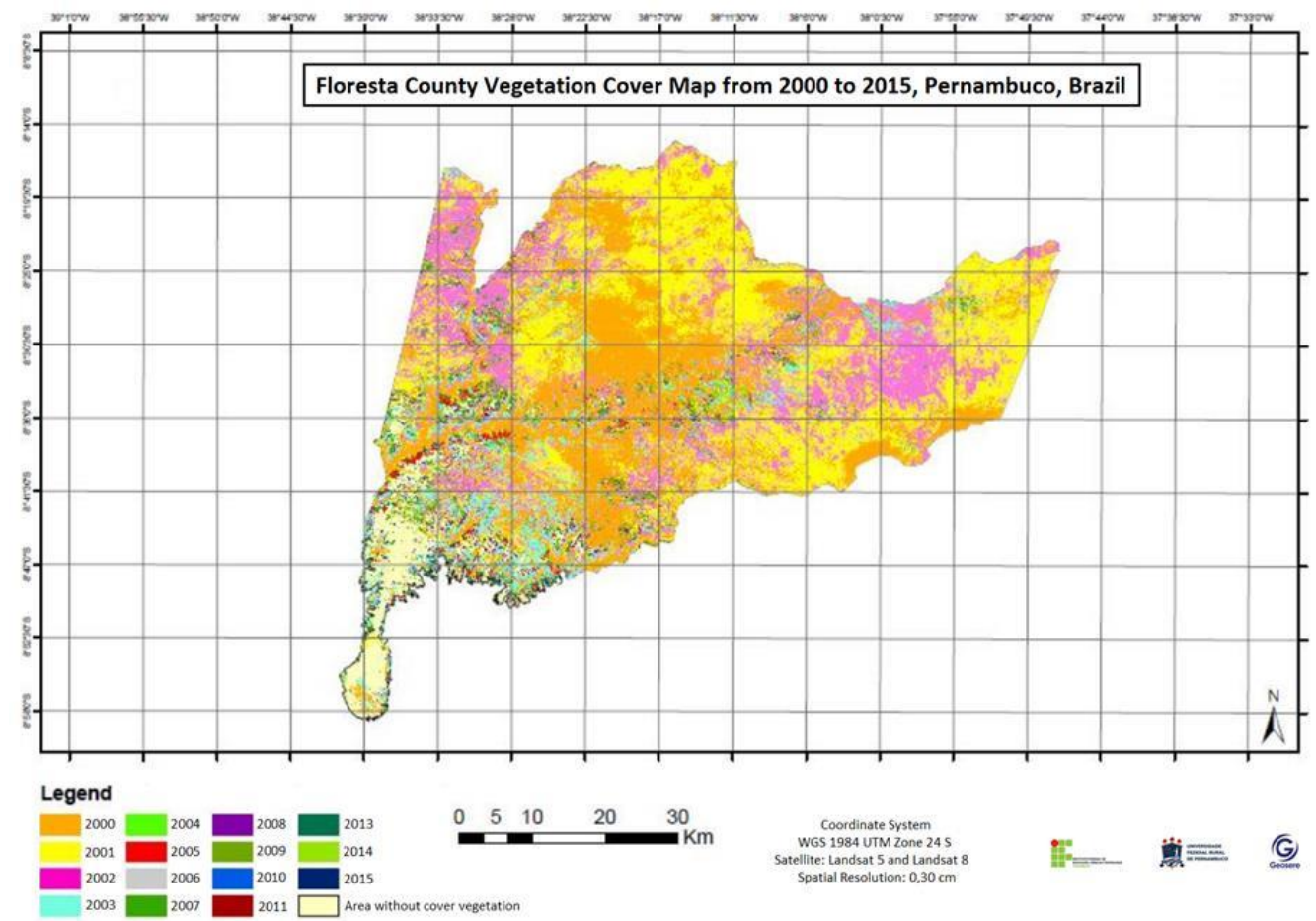

Figure 7 - Floresta county vegetation coverage map. 


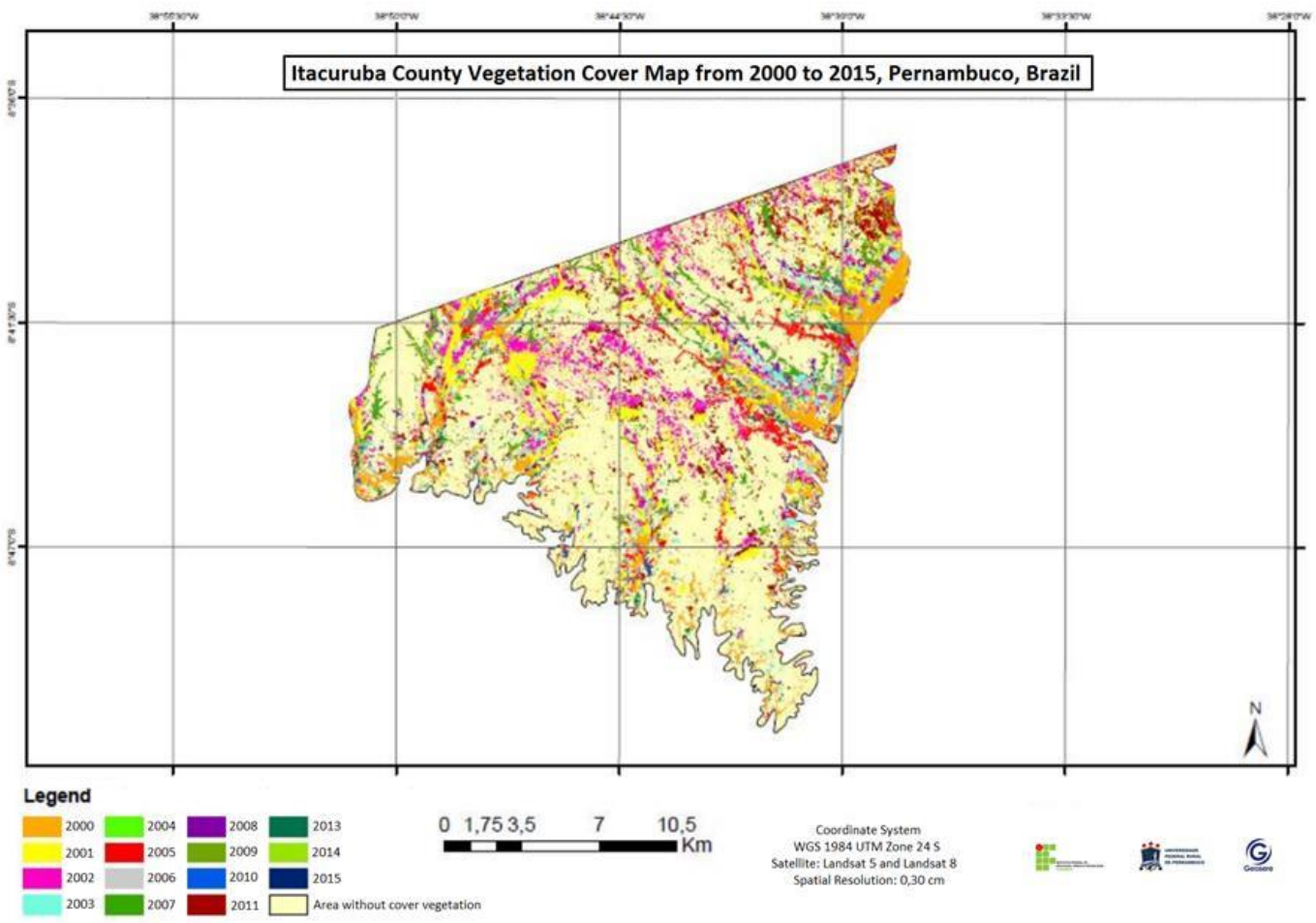

Figure 8 - Itacuruba county vegetation coverage map.

From the previously described methodology, it was possible to evaluate the percentage of vegetation cover of the years studied, by municipality (Table 4, 5 and 6).

From the generation of vegetation cover data for each county, it was possible to develop Graphs the percentage of the values of areas with and without vegetation cover and the value corresponding to dry periods (with precipitation) and rainy period (without precipitation).

As mostly temporary crops in the municipalities studied, in the presence of vegetation cover, especially in the shrub vegetation of irrigated agriculture areas of studied areas, it is not allowed to offer soil protection against desertification processes, as addressed by Gois et al. (2015).

Table 4 - Betânia county vegetation cover data.

\begin{tabular}{cccc}
\hline Year & Vegetation $\left(\mathbf{k m}^{\mathbf{2}}\right)$ & County $\left(\mathbf{k m}^{\mathbf{2}}\right)$ & \% \\
\hline 2000 & 20,18 & 1244,07 & 1,62 \\
2001 & 63,25 & 1244,07 & 5,08 \\
2002 & 327,51 & 1244,07 & 26,31 \\
2003 & 47013 & 1244,07 & 3,79 \\
2004 & 31,83 & 1244,07 & 2,56 \\
2005 & 18,49 & 1244,07 & 1,49 \\
2006 & 65,33 & 1244,07 & 5,25 \\
2007 & 402,84 & 1244,07 & 32,38 \\
2008 & 14,30 & 1244,07 & 1,15 \\
2009 & 17,97 & 1244,07 & 1,44 \\
2010 & 11,84 & 1244,07 & 0,95 \\
2011 & 564,74 & 1244,07 & 45,39 \\
2013 & 4,20 & 1244,07 & 0,34 \\
2014 & 161,54 & 1244,07 & 12,99 \\
2015 & 249,25 & 1244,07 & 20,04 \\
\hline
\end{tabular}

Table 5 - Floresta county vegetation cover data.

\begin{tabular}{cccc}
\hline Year & Vegetation $\left(\mathbf{k m}^{\mathbf{2}}\right)$ & County $\left.\mathbf{( k m}^{\mathbf{2}}\right)$ & \% \\
\hline 2000 & 341,22 & 3644,168 & 9,36 \\
2001 & 914,44 & 3644,168 & 25,09 \\
2002 & 1381,46 & 3644,168 & 37,91 \\
2003 & 841,35 & 3644,168 & 23,09 \\
2004 & 156,77 & 3644,168 & 4,30 \\
2005 & 182,6 & 3644,168 & 5,01 \\
2006 & 459,03 & 3644,168 & 12,60 \\
2007 & 1299,13 & 3644,168 & 35,65 \\
2008 & 266,56 & 3644,168 & 7,31 \\
2009 & 1324,83 & 3644,168 & 36,35 \\
2010 & 154,01 & 3644,168 & 4,23 \\
2011 & 864,72 & 3644,168 & 23,73 \\
2013 & 864,73 & 3644,168 & 23,73 \\
2014 & 1372,98 & 3644,168 & 37,68 \\
2015 & 642,02 & 3644,168 & 17,62 \\
\hline
\end{tabular}

Table 6 - Itacuruba county vegetation cover data.

\begin{tabular}{cccc}
\hline Year & Vegetation $\left(\mathbf{k m}^{\mathbf{2}}\right)$ & County $\left(\mathbf{k m}^{\mathbf{2}}\right)$ & $\mathbf{\%}$ \\
\hline 2000 & 14,48 & 430,038 & 3,37 \\
2001 & 25,93 & 430,038 & 6,03 \\
2002 & 24,45 & 430,038 & 5,68 \\
2003 & 6,08 & 430,038 & 1,41 \\
2004 & 7,47 & 430,038 & 1,74 \\
2005 & 18,13 & 430,038 & 4,22 \\
2006 & 9,19 & 430,038 & 2,14 \\
2007 & 11,30 & 430,038 & 2,63 \\
2008 & 7,83 & 430,038 & 1,82 \\
2009 & 11,74 & 430,038 & 2,73 \\
2010 & 11,57 & 430,038 & 2,69 \\
2011 & 20,26 & 430,038 & 4,71 \\
2013 & 5,52 & 430,038 & 1,28 \\
2014 & 11,56 & 430,038 & 2,69 \\
2015 & 5,32 & 430,038 & 1,24 \\
\hline
\end{tabular}


Figure 9 below shows the percentage of areas with and without vegetation cover in the city of Betânia. It can be observed that dry period, the municipality of Betânia has approximately $0.34 \%$ of vegetation cover, ie, if there is no rain, the municipality will have a vegetation cover equivalent to an area of $4.2 \mathrm{~km}^{2}$.

Following this same thought, if there were always high levels of precipitation in the municipality, the area without vegetation corresponds to a percentage of approximately $54 \%$, which corresponds to $1239.87 \mathrm{~km}^{2}$. Thus, it can be observed that $54 \%$ of areas without vegetation cover may be at risk of desertification process.

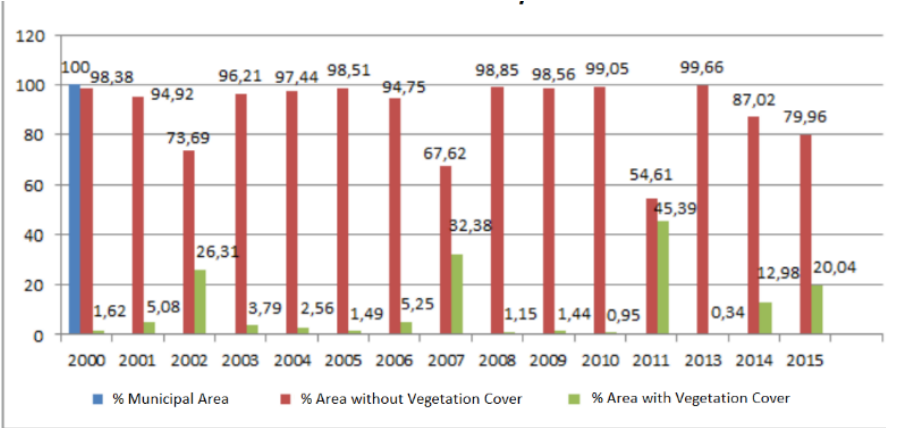

Figure 9 - Betânia county vegetation cover graph.

For the municipality of Floresta (Figure 10), it can be observed that in the worst case - dry and no precipitation periods - the municipality has, of course, approximately $4 \%$ of vegetation cover, ie, if there is no rain, the municipality it will have an equivalent area of $154 \mathrm{~km}^{2}$. For this, in the best hypothesis - periods with precipitation - the area without vegetation cover is approximately $62 \%$, which is $2259.4 \mathrm{~km}^{2}$.

Thereby, if there is, to the best of our ability, high precipitation rates, the area of the municipality with vegetation corresponds to a percentage of approximately 37\%, which equals the area of 11381 $\mathrm{km}^{2}$. The municipal area without vegetation cover is approximately $67 \%$ and corresponds to an area of $2262.8 \mathrm{~km}^{2}$.

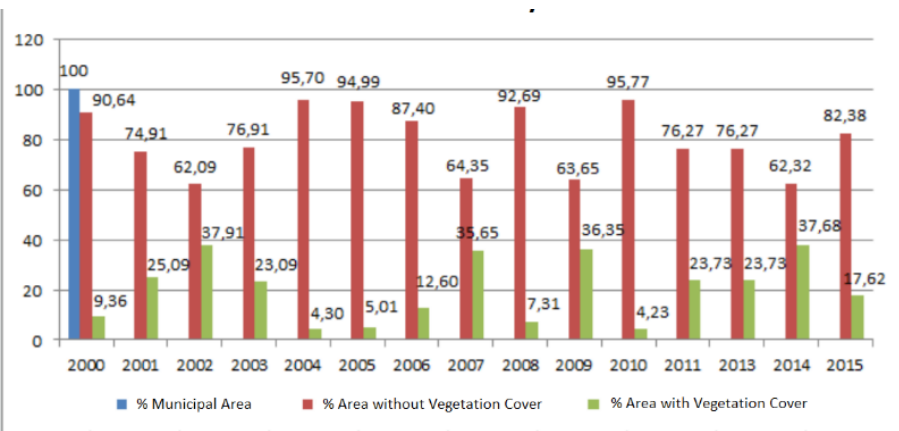

Figure 10 - Graph of vegetation cover in the municipality of Floresta.
In the context of the municipality of Itacuruba (Figure 11) it can be observed that at worst - dry and without precipitation - the municipality has approximately $1 \%$ of vegetation cover, ie, if there is no rain, the municipality will have an area of equivalent plant cover $5 \mathrm{~km}^{2}$. For this, the area without vegetation coverage is equivalent to approximately $99 \%$ of the municipality, which is equivalent to approximately $420 \mathrm{~km}^{2}$.

In the high precipitation rates - best of all the area with vegetation cover of the municipality corresponds to a percentage of approximately 6\%, which corresponds to an area of approximately 25 $\mathrm{km}^{2}$. The municipal area without vegetation would be $94 \%$ and corresponds to approximately $400 \mathrm{~km}^{2}$.

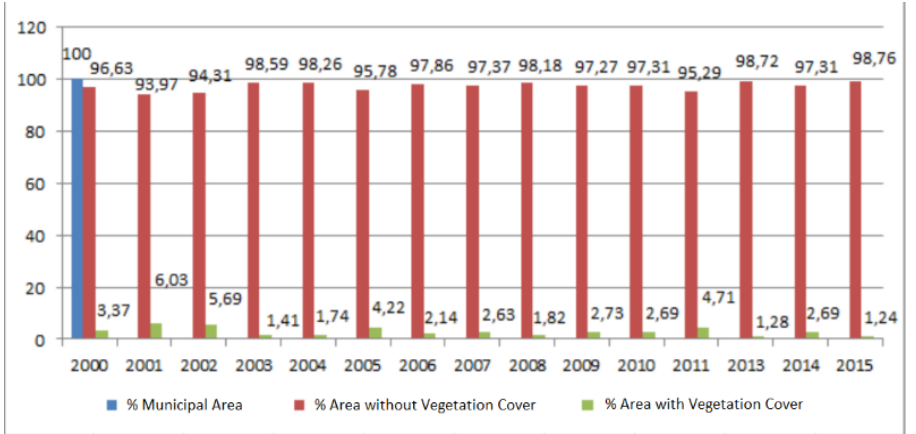

Figure 11 - Graph of vegetation cover in the municipality of Itacuruba.

A problem related to exposed soil is the increase in surface temperature. Soares et al. (2010), in a study conducted in the state of Pernambuco, detected impacts related to the deforestation and temperature increase of soil surface. Highlight for the increase in evaporation of soil moisture and migration of termites of soil for vegetation.

The sparse caatinga contributes to the risks soil erosion contributing to the advance desertification potential (Santos and Galvíncio, 2013). The same can be highlighted for the areas of exposed soil identified over the municipalities. Porting the region has moderate risk for areas susceptible to desertification. (Silva et al., 2017).

Thus, it was possible to calculate the ICV, where it can be seen from the data presented above, that Itacuruba is the municipality which has the lowest vegetation coverage even in periods with high precipitation rates, ie, this municipality has low vegetation even occurring rain.

From the vegetation cover percentage, the vegetation cover index was calculated, where the ICV values were obtained according to Table 7 . 
Table 7 - Counties Vegetation Cover Index.

\begin{tabular}{cc}
\hline County & ICV $^{*}$ \\
\hline Betânia & 3 \\
Floresta & 2 \\
Itacuruba & 4 \\
\hline
\end{tabular}

*Vegetation Cover Index

Accordingly, based on the vulnerability scale mentioned in the methodology, a vulnerability ICV in the municipality of Floresta has a weight of 2 divided by 4 , corresponding to a value of 0,5 on the vulnerability index scale. For Betânia, the weight 3 divided by 4 corresponds to the value 0,75 . And for Itacuruba, the value 4 divided by 4 refers to the value 1 on the vulnerability scale (Figure 12).

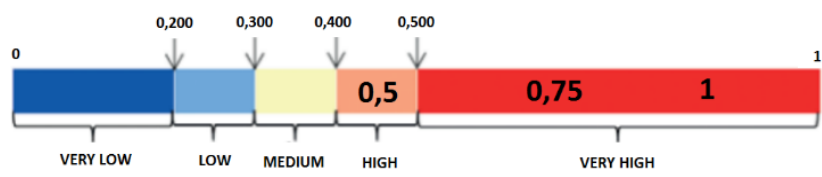

Figure 12 - Vegetation Cover Index (IVC) value on the vulnerability scale.

It is possible to verify, due to the ICV highest vulnerability value, that the municipality of Itacuruba and Betânia has very high environmental and population vulnerability related to the desertification process, because the vegetation deficit influences the hydrological dynamics, soil protection, stability climate and thermal influence. Floresta, on the other hand, has high vulnerability because it has a larger municipal area and greater vegetation cover.

\section{Conclusions}

Thus, the work developed was effective for information generation, monitoring of the vegetation cover of the municipalities studied in the desertification process. It was found that the lack of vegetation cover associated with anthropic actions directly influence the vulnerability of municipalities for generation.

The municipality of Itacuruba showed the highest environmental vulnerability in the desertification process, as the vegetation deficit influences hydrological dynamics, soil protection, climate stability and thermal influence. Therefore, a very high ICV.

Betânia, on the other hand, has high vulnerability, and Forest, because it has a larger municipal area and greater vegetation cover, has intermediate vulnerability.

Recognition by the State and Municipal Governments of the issue of vulnerability to desertification to develop effective public policies is fundamental for improving the population's quality of life.
Further studies of the other General Vulnerability Indexes (IVG) are recommended to more fully assess the environmental and population vulnerability to the desertification processes of these municipalities, and to develop the Human Vulnerability Indexes (IVH) against projections. future climate change.

\section{Agradecimentos}

To the Graduate Program of the Federal Institute of Education, Science and Technology of Pernambuco. To the Coordination of the Professional Master in Environmental Management. To the Geoprocessing and Remote Sensing Laboratory GEOSERE / UFRPE. To the second and third authors for the guidelines. To the fourth and fifth authors for their contributions.

\section{References}

Araújo Filho, J.C., Carvalho, A., Silva, F.B.R., 2001. Investigações preliminares sobre a pedogênese de horizontes coesos em solos dos tabuleiros costeiros do Nordeste do Brasil. Workshop Coesão em Solos dos Tabuleiros Costeiros. Aracaju.

Civitello, D.J., 2015. Biodiversity inhibits parasites: broad evidence for the dilution effect. Proceeding of the National Academy of Science of the United States of America.

CPRM. Serviço Geológico do Brasil, 2005. Diagnóstico do Município de Betânia. Recife.

Field, C.B., 2014. Climate Change 2014: Impacts, Adaptation, and Vulnerability. Part A: Global and Sectoral Aspects. Contribution of Working Group II to the Fifth Assessment Report of the Intergovernmental Panel on Climate Change. Cambridge.

Galindo, I.C.L, Ribeiro, R.R, Santos, M.F.A.V, Lima, J.F.W.F, Ferreira, R.F.A.L., 2008. Relações solo-vegetação em áreas em processo de desertificação no município de Jataúba-PE. Revista Brasileira de Ciências do Solo 32, 12831296.

Gois, D.V., Melo, F.P, Araújo, W.S., Souza, T.M. 2015. Índices de vegetação e suscetibilidade à desertificação no município de Poço Redondo Sergipe. GeoAlagoas. Maceió.

IBGE. Instituto Brasileiro de Geografia e Estatística, 2010a. Infográficos: dados gerais do município de Betânia, PE. Censo 2010. Rio de Janeiro.

IBGE. Instituto Brasileiro de Geografia e Estatística, 2010b. Infográficos: dados gerais do município de Itacuruba, PE. Censo 2010. Rio de Janeiro.

IPEA. Instituto de Pesquisa Econômica Aplicada, 2015. Atlas da Vulnerabilidade Social nos 
Municípios Brasileiros. Brasília.

Mccarthy, J.J, Canziani, O.F, Leary, N.A, Dokken, D.J, White, K.S., 2001. Climate Chenge 2001: impacts, adaptations, and vulnerability. University of Cambridge, Cambridge.

Rocha Filho, G.B. 2016. Estudo do potencial agrícola e não agrícola do município de Itacuruba, Pernambuco, Brasil. Dissertação (Mestrado). Recife, IFPE.

Rodal, M.J.N., Sampaio, E.V.S., Figueiredo, M.A., 1992. Manual de Métodos sobre Estudo Florístico e Fitossociológico - ecossistema caatinga. Sociedade Botânica do Brasil, Brasília.

Rodrigues, W., 1997. Pesquisa dos estudos e dados existentes sobre desertificação no Brasil. Ministério do Meio Ambiente. Plano Nacional de Combate à Desertificação. PROJECT BRA 93/036.

Santos, A.M., Galvíncio, J.D., 2013. Mudanças Climáticas e Cenários de Susceptibilidade Ambiental à Desertificação em Municípios do Estado de Pernambuco. Observatorium: Revista Eletrônica de Geografia 5, 24-47.

Sales, M.C.L., 2002. Evolução dos Estudos de desertificação no nordeste brasileiro. GEOUSP 1, 115-126.

Sá, I.B, Cunha, T.J.F, Taura, T.A, Drumond, M.A.,
2015. Mapeamento da desertificação da região de desenvolvimento Sertão do São Francisco com base na cobertura vegetal e nas classes de solos. Revista Brasileira de Geografia Física 8, 510-524.

Silva, H.P., 2009. Mapeamento das áreas sob risco de desertificação no semiárido de Pernambuco a partir de imagens de satélites. Tese (Doutorado). Recife, UFRPE.

Silva. J.N.B., Silva, J.L.B., Silva, A.C., Santos, A.M., Galvíncio, J.D., 2017. Índice de vegetação como subsídio na identificação de áreas com potenciais a desertificação. Journal of Environmental Analysis and Progress 2, 358-367.

Soares, D.B, Filho, F.O.M., Nobrega, R.S., Oliveira, T.H., 2010. Geoprocessamento e sensoriamento remoto como ferramentas de desertificação de áreas em processo de desertificação, in: Galvíncio, J.D. (Orga.), Mudanças Climáticas e Impactos Ambientais. EDUPE, Recife, pp. 35-56.

Souza, B.I, Antunes, D.M.S, Rodrigues, E.V.L., 2009. Desertificação e seus efeitos na vegetação e solos do cariri paraibano. Mercator Revista de Geografia 8, 217-232.

Vasconcelos Sobrinho, J., 1978. Metodologia para Identificação de Processos de Desertificação: manual de indicadores. SUDENE, Recife. 